\title{
The Perceptions on IIA's Standards and Internal Audit Quality: Evidence from Albania Banking Industry
}

\author{
Mustafa Üç \\ Edvin Haxhiraj \\ Epoka University, Tirana \\ Email:muc@epoka.edu.al
}

Doi:10.5901/mjss.2015.v6n1p147

\begin{abstract}
This paper aims to demonstrate and evaluate perceptions of internal auditors towards the Institute of Internal Auditors' (IIA) standards, and to indicate the relationship between perceived standards that influence the quality of internal audit in Albania's banking industry. In order to achieve these objectives, a questionnaire was prepared and distributed to internal auditors actively working in the banking industry. The statements of questionnaire were based on the IIA's standards. The use of these standards is essential for industry because they are recommended by the Basel Committee on Banking Supervision for providing a strong internal audit function within the banking organizations. It is concluded that the internal auditors comply with the principles defined in the standards, considering these principles necessary for the quality of the internal audit. This research presents very positive internal auditors' perceptions on the attribute standards and performance standards respectively (4.42) and (4.41), besides, there are moderate positive relations between perceptions of performance and attribute standards and internal audit quality. Lastly, to explore whether there are any significant differences or not between the demographic components; gender, experience and perceptions of the attribute and performance standards, Independent t-test and ANOVA have been applied. According to results of the t-tests (used for gender) and ANOVA (used for work experience) there are not any perception differences on the attribute and performance standards by gender and work experience of the respondents.
\end{abstract}

Keywords: Internal audit, internal audit quality, IIA's standards, attribute standards, performance standards, banking Industry, Albania.

\section{Introduction}

Banks are responsible for organizing an internal audit system to monitor the implementation of internal policies and procedures, the evaluation of effectiveness of banking activity and compliance with laws and regulations. The internal audit unit is a part of the bank's internal audit system which has a good impact on the effectiveness of banking operations (Salehi, Arianpoor and Salehi, 2013).

The Basel Committee on Banking Supervision promotes a strong internal audit function within banking organizations and, in addition, it also encourages bank internal auditors to comply with, and contribute to the development of national and international professional standards, such as those issued by the Institute of Internal Auditors (IIA) (Bank for International Settlements, 2012 [BIS]).

Considering the importance of internal audit role as part of sound corporate governance and banks' internal control system as well, through this paper we aim to evaluate perceptions of internal auditors toward IIA's standards and to indicate the relationship between perceived standards that influence the perceived quality of internal audit in Albania's banking industry.

In order to fulfill the scope of this research, a questionnaire was compiled and delivered to internal auditors involved in banking industry. The statements of the questionnaire were based on the International Standards for The Professional Practice of Internal Auditing (Standards) issued by IIA. The significant contribution of the study consists on the fact of being the very first one to exhibit perceptions of internal audit standards by its users in banking industry of a former half a century-communist country like Albania.

The internal auditors' compliance of IIA standards have been examined by many researches in different countries (Burnaby \& Hass, 2011; Abdolmohammadi, 2009; Steyn, Barac, Motubatse, \& Plant; Abdolmohammadi \& Sarens, 2011). The common point of these studies is that they used the data from a worldwide study named Common Body of Knowledge (CBOK) database which is issued by IIA. However, this study distinguishes from those studies examining the internal auditors' perceptions on the standards in a country that was central planned economy in the past and used a 
specific survey in the data collection derived from direct standards.

This paper is organized as following: In the next chapter we provide an institutional background about standard setter and standards. In chapter three, we provide a literature review on the topic. In chapter four we discuss the research methodology and findings, and finally, in chapter five we present the study's conclusions.

\section{Standard Setter: The Institute of Internal Auditors and Standards}

The Institute of Internal Auditors (IIA) is the international professional association founded in the United States in 1941. The IIA is the internal audit profession's global voice, recognized authority, acknowledged leader, chief advocate, and principal educator (The Institute of Internal Auditors [IIA], 2014). The standards are the product of rigorous working and unified set of rules for the practicing of internal auditing in worldwide (Abdolmohammadi, 2009).

\subsection{Attribute Standards and Performance Standards}

The structure of the standards is divided between attribute and performance standards. Attribute standards address the attributes of organizations and individuals performing internal auditing and is applied to all internal audit services and internal auditors individually. Performance standards describe the nature of internal auditing and provide quality criteria against which the performance of these services can be measured. Similar to attribute standards, performance standards apply to all internal audit services as well as internal auditors (IIA'standards, 2010).

\section{Internal Audit Quality}

There is not a common definition for audit quality term in internal or external (independent) auditing literature. However, there has been extracted from the prior researches a two dimensional definition which has been stressing independency and objectivity as the main contributors to the audit quality. According to this definition, regardless of internal or external, the audit quality has been defined as the ability to discover and report the irregularities and/or breaches; the latter is the most prominent indicator of audit quality (Butcher, Harrison \& Ross, 2013; Daniels \& Booker, 2011).

The degree of the quality in discovering and reporting irregularities and breaches depends on proficiency, independency and objectivity (Al Matarneh, 2011). On the other hand, expectations from the a proper internal audit function encompass: controlling of effectiveness and efficiency of operations, degree of the success of compliance in regulations and internal procedures, reliability of financial reporting and safeguarding of assets (Hayes, Dassen, Schilder \&Wallage, 2005). In this context, one can point out that satisfaction of the expectations placed above demonstrates the degree of the quality of the internal audit activities. In order to measure internal audit quality, this approach which has been used by Al Matarneh in 2011, has also been adapted and implemented in this research.

\section{Literature Review}

There is abundant previous literature on internal audit worldwide, in contrast though very little in Albania. We mention significant studies worldwide and in Albania.

Steyn, Barac, Motubatse, \& Plant (2013) analysed the survey results of CBOK 2010 for continent of Africa . Slightly more than half of the respondents confirmed that they fully comply with the standards. The lowest values appeared in compliance with an attribute standard "quality assurance and improvement program" and in compliance for a performance standard "management's acceptance of risk".

Karcioglu and Yanik (2010) conducted a questionnaire to examine the degree of compliance of standards in the largest 500 manufacturing companies in Turkey. It was found that the degree of compliance is high though there are significant differences amongst the analyzed companies by some demographic data such as the number of employee and sectors.

Al Matarneh (2011) aimed to determine the internal audit quality in banks of Jordan. A questionnaire has been designed and used,and whose results indicate that internal auditors in Jordanian banks consider the competence, objectivity, and performance of internal auditors as important factors affecting the internal audit quality. The study recommended that Jordanian banks must work to ensure the availability of the key factors to achieve the quality of the internal audit function (Al Matarneh, 2011).

Faudziah, Hasnah, \& Muhamad (2005) in their study intended to determine whether the internal audit department of the companies listed in the Sock Exchange of Bursa Malaysia complies with the Standards for the Professional 
Practice of Internal Auditors IIA (2000); and, to determine whether compliance to SPPIA will affect the quality of the internal control system of the company. - It was found that management of internal audit department; professional proficiency, objectivity and review significantly influence the monitoring aspect of the internal control system.

Furthermore, the scope of work and performance of audit significantly influences the information and communication aspect of the internal control system while performance of audit, professional proficiency and objectivity significantly affect the control environment aspect of the internal control system. The study also shows that management of internal audit department, performance of audit, audit program and audit reporting significantly influences the risk assessment aspect of the internal control system. Lastly, performance of audit work and audit reporting significantly influences the control activities aspect of the internal control system.

Brody and Lowe (2003) in their survey investigate whether internal auditors view their consulting role as one in which they have to provide objective feedback to management or one in which they are to provide solutions that they believe are in the best interests of their company. Specifically, they examine whether the internal auditors' judgments are dependent on their company's role (buyer or seller) in an acquisition. Results revealed that the role of the company in the negotiation process did influence judgments. This suggests that internal auditors are likely to assume the position that is in the best interests of their employer (Brody et al, 2003).

Regulators and small audit firms allege that audit firm size does not affect audit quality and therefore should be irrelevant in the selection of an auditor. Contrary to this view, DeAngelo (1981) in her survey argue that audit quality is not independent of audit firm size, even when auditors initially possesses identical technological capabilities (DeAngelo, 1981).

Savčuk (2007) in his article analyses efficient internal audit establishment and support issues and internal audit efficiency estimation principles. Taking into account the scope of organization's direction and control, internal audit takes on important roles, integrating several other governance and control aspects into organizational governance. Thus it stands out as the most important, single mechanism for ensuring adequate and effective governance of the organization. The article provides criteria to assess efficiency of internal audit which could be applied when implementing internal audit function or improving the existing one. The efficiency and development level of internal audit functions were researched applying Internal Audit Efficiency Score (IAES) that is created taking into account the four main internal audit implementation areas that are: Internal audit subordination, qualification of internal auditors, internal audit strategy, and internal audit efficiency estimation.

Moreover, IAES score is a practical means which can be used while implementing internal audit function or improving the existing one. Practical application of IAES was done analyzing 38 Lithuanian companies having internal audit function, estimating its efficiency and development level. The research indicated that the major part of these companies have internal audit function corresponding to the $1^{\text {st }}$ or $2^{\text {nd }}$ efficiency level (i.e. 13and 18 companies accordingly). Therefore IAES score can be a very useful tool for Lithuanian companies improving their internal audit function efficiency or implementing internal audit in those companies, which still do not have it (Savčuk, 2007).

With regard to internal audit function in banking industry; Gill, Hernandez, and de Lema (2012) examined 47 banks' internal audit function and quality of financial reporting with collecting the data by a questionnaire in Spain. They found that greater involvement of internal audit in reviewing financial reports leads to improved quality of financial reporting.

In order to view and assess the previous literature performed in Albania in the field of internal audit, following literature found that:

The use or perceptions of IIA's standards have not been researched extensively in Albania. The researches which have most similar topics were reviewed here.

Shkurti, Leka, Bahiti, and Manoku (2011) presented a theoretical discussion about the organization of professions of accounting and auditing in Albania and the most recent changes that have encompassed the Albanian financial and accounting landscape after the implementation of new accounting standards, the increased requirements for electronic financial and tax reporting and the ongoing improvement and adaptation of the higher education curricula. All these factors present major challenges for the field practitioners in accounting and auditing. They tried to identify which are the most prominent challenges faced by the practitioners today and identify that the Information and Communication Technology (ICT) impact, ethical values and the globalization trend in accounting and financial reporting are some of the most emergent ones. These factors make the work of practitioners more and more demanding and, as it seems difficult to remain competitive in such a dynamic environment, they concluded with the recommendations that the curricula of the financial and accounting higher education should be adapted to include topics such as IAS/IFRS, ICT, Code of Ethics and that the professional accountancy and auditing organizations in Albania should provide ongoing training and qualification sessions on the same topics to the existing practitioners.

Muceku and Korsita (2010) discussed the role of internal auditing in the improving and development of 
management and value of public entities in Albania. They denounce that internal audit in public entities does not meet the requirements that are put forward by internal audit law. The lack of knowledge of auditors, deviations from audit schedules are counted as fundamental problems besides some structural problems in the place of internal audit and communication problems among the institutions.

\section{Research Methodology}

The banking system in Albania has a two-tier structure. In the first tier is included the Bank of Albania (BoA), which is the central bank of Albania, whereas in the second one, Banks and non-bank financial institutions licensed by the Bank of Albania (bankofalbania.org).

According to the BoA's supervision annual report 2011 the banking system is the main financial intermediary in Albania and that the number of the banks in Albania as of end 2011 is 16 banks (bankofalbania.org).

The objectives of this research are to reveal internal auditors' perceptions toward IIA's standards and to indicate the relationship between perceived standards that influence the perceived quality of internal audit in Albania's banking industry. To achieve these research objectives, perceptions of the internal auditors can be collected by either interviews or conducting a standard questionnaire. We chose to conduct a questionnaire in accordance with our research objectives that to determine the perceptions of internal audits on IIA's standards. IIA's standards have many items which were taken places as statements of the questionnaires. Owing to population of research is consist of 88 internal auditors and numerous statements, could be asked only by a standard questionnaire. On the other hand likert-scale questionnaire enabled to test relationship between perceptions of internal auditors on IIA standards and audit quality by using correlation analysis.

\subsection{Data}

In September 2012, a questionnaire was conducted on the factors influencing the quality of internal audit in the Albanian banking sector by distributing a questionnaire to internal auditors working in this sector. The study population consists of 16 Banks operating in Albania, with total number of the internal auditors to 88. We tried to reach to all the population, while the number of received responses was 33 from 13 different banks, corresponding to $37.5 \%$ of internal auditors' total population and being from $81 \%$ of banks operating in Albania.

\subsection{Research Method}

The data were collected through a questionnaire designed depending on IIA's standards and benefited from Al Matarneh's (2011) questionnaire which measures factors determining internal audit quality in the banks of Jordan. The questionnaire contains two parts; the first part included demographic characteristics of the respondents, while the second part covers the respondents' perceptions toward the statements.

Five-Likert scale has been used to measure the views of respondents regarding the statements presented in the questionnaire, which were allocated as follows; (5) for the situation strongly agree, (4) for agree, (3) for the situation is neutral, it specified with 'Neither agree nor disagree' (2) for disagree, and (1) for Strongly Disagree.

The questionnaire has been introduced also to the supervisor of this thesis for the purpose of settlement. Arithmetic mean, standard deviation and percentages were used in the quarterly analysis of the responses to the questionnaire.

The internal reliability of the scale used in this research was measured with Cronbach's Alpha. The amount of Cronbach's alpha reached was at (0.919), which indicates high level of internal consistency for our scale (Sekaran \& Bougie, 2010).

\subsection{Research Hypothesis}

Hypothesis of this research are as follows:

$\mathrm{H} 1$ There is a positive relationship between attribute standards and the quality of the internal audit. $\mathrm{H} 2$ There is a positive relationship between performance standards and the quality of the internal audit. 


\subsection{Research Model}

The measurement of how strong is the relationship between the independent variables attribute standards, performance standards and the dependent variable internal audit quality is performed through the following correlation coefficient model.

$$
\begin{aligned}
& r=\frac{\mathbf{n}\left(\sum \mathbf{x y}\right)-\left(\sum \mathbf{x}\right)\left(\sum \mathbf{y}\right)}{\sqrt{\left[\mathbf{n} \sum \mathbf{x}^{2}-\left(\sum \mathbf{x}\right)^{2}\right]\left[\mathbf{n} \sum \mathbf{y}^{2}-\left(\sum \mathbf{y}\right)^{2}\right]}} \\
& \text { Where: } \\
& r=\text { Pearson correlation } \\
& \mathrm{n}=\text { Sample size } \\
& \mathrm{x}=\text { Dependent variable; } \\
& \mathrm{y}=\text { Independent variable }
\end{aligned}
$$

The variables used in this research model are as following:

The independent variables are the factors defined by attribute and performance Standards of the Internal Auditors, which have been measured respectively by 12 statements, while the dependent variable is the internal audit quality that has been identified by 5 statements.

\subsection{Research Findings: Demographic Information}

To help understand the composition of the respondents, several demographic related questions were asked.

From the table (1) it can be noted that $33 \%$ of respondents hold a bachelor degree and $61 \%$ of them have a master degree. While regarding their professional experience in the audit function the majority of responders $64 \%$ have had less than 5 years experience in internal auditing, $30 \%$ of them have had experience in this function from 5 to 10 years, while only $6 \%$ of the respondents have had experience from 10 to 20 years.

Table 1. Respondents' Demographic Information

\begin{tabular}{|c|c|c|c|}
\hline Variable & Variable Categories & Frequency & $\%$ \\
\hline \multirow{3}{*}{ Qualifications } & High School & 1 & 3 \\
& Bachelor's Degree & 11 & 33 \\
& Master's Degree & 20 & 61 \\
& Missing & 1 & 3 \\
\hline \multirow{2}{*}{ Experience } & From 1-5 years & 21 & 64 \\
& From 5-10 years & 10 & 30 \\
& From 10-20 years & 2 & 6 \\
\hline \multirow{2}{*}{ Gender } & Male & 15 & 45 \\
& Female & 18 & 55 \\
\hline \multirow{2}{*}{ Nationality } & Albanian & 1 & 97 \\
& Other & 32 & 3 \\
\hline
\end{tabular}

\section{Independent Variable: Influencing Factors of the Internal Audit Quality}

Attribute Standards: Twelve factors were used to reflect the attributes standards. In table (2) below are provided the results of the questionnaire concerning the level of agreement given by internal auditors to each factor of the attribute standards. The table shows that the overwhelming majority of the respondents considers factors such as:

Establishment of internal audit charter that articulates the purpose, standing and authority of the internal audit function;

Definition of internal auditing, the code of ethics, and the standards in the internal audit charter;

Direct communication and interaction of the chief audit executive with the bank's board of directors;

Appointment of internal auditors, the promotion, rewards, and lay off by the audit committee or board of directors; internal auditors' impartial, unbiased attitude and conflict of interests avoidance;

Threats to independence and objectivity management at the individual auditor, engagement, functional, and organizational levels;

Suitable audit methodologies and tools necessity to increase the effectiveness of the bank's internal audit function;

Appropriate and ongoing training to audit staff necessity aiming to meet the growing technical complexity of banks' 
activities;

Internal auditors' knowledge, skills, and other competencies enhancement through continuous professional development (i.e. professional certificate obtained). Development of quality assurance and improvement program that covers all aspects of the internal audit activity; Include of both internal and external assessments for the quality assurance and improvement program;

Communication of the results of the quality assurance and improvement program to senior management and the board of directors.

The arithmetic means of the respondent's answers of this field are high reached to (4.52), and the standard deviations were $(0.40)$.

Table 2. Factors influencing the Attribute Standards

Descriptive Statistics

\begin{tabular}{|l|c|c|}
\hline Statements & Mean & Std. Deviation \\
\hline $\begin{array}{l}\text { Establishment of internal audit charter that articulates the purpose, standing and authority of } \\
\text { the internal audit function. }\end{array}$ & 4.79 & 0.415 \\
\hline $\begin{array}{l}\text { The Definition of Internal Auditing, the Code of Ethics, and the Standards must be } \\
\text { recognized in the internal audit charter. }\end{array}$ & 4.58 & 0.663 \\
\hline $\begin{array}{l}\text { The chief audit executive must communicate and interacts directly with the Bank's Board of } \\
\text { Directors. }\end{array}$ & 4.36 & 0.994 \\
\hline $\begin{array}{l}\text { The appointment of internal auditors, the promotion, rewards, and lay off must be performed } \\
\text { by the audit committee or Board of Directors. }\end{array}$ & 4.18 & 0.769 \\
\hline Internal auditors must have an impartial, unbiased attitude and avoid the conflict of interests. & 4.76 & 0.614 \\
\hline $\begin{array}{l}\text { Threats to independence and objectivity must be managed at the individual auditor, } \\
\text { engagement, functional, and organizational levels. }\end{array}$ & 4.33 & 0.854 \\
\hline $\begin{array}{l}\text { Suitable audit methodologies and tools are needed to increase the effectiveness of the } \\
\text { bank's internal audit function. }\end{array}$ & 4.64 & 0.489 \\
\hline $\begin{array}{l}\text { Appropriate and ongoing training to audit staff are needed to meet the growing technical } \\
\text { complexity of banks' activities. }\end{array}$ & 4.55 & 0.506 \\
\hline $\begin{array}{l}\text { Internal auditors must enhance their knowledge, skills, and other competencies through } \\
\text { continuing professional development (i.e. professional certificate obtained). }\end{array}$ & 4.45 & 0.506 \\
\hline $\begin{array}{l}\text { The chief audit executive must develop a quality assurance and improvement program that } \\
\text { covers all aspects of the internal audit activity. }\end{array}$ & 4.33 & 0.692 \\
\hline $\begin{array}{l}\text { The quality assurance and improvement program must include both internal and external } \\
\text { assessments. }\end{array}$ & 4.03 & 0.847 \\
\hline $\begin{array}{l}\text { The results of the quality assurance and improvement program must be communicated to } \\
\text { Senior Management and the Board of Directors. }\end{array}$ & 4.15 & 4.42 \\
\hline TOTAL FIELD & 0.870 \\
\hline
\end{tabular}

Performance Standards: Twelve factors were used to reflect the performance standards. In table (3) are provided the results of the questionnaire concerning the level of importance given by internal auditors to each factor. The table shows that the overwhelming majority of the respondents consider factors such as:

Establishment of risk-based plans to determine the priorities of the internal audit activity, consistent with the organization's goals;

Communication of the internal audit activity's plan and resource requirements to senior management and the board for review and approval;

Proper insurance that the internal audit resources are appropriate, sufficient, and effectively deployed to achieve the approved plan;

Establishment of policies and procedures to guide the internal audit activity; Share of information and coordination of activities with other internal and external providers of assurance and consulting services to ensure proper coverage and minimize duplication of efforts;

Evaluation of the risk exposures relating to the organization's governance, operations, and information systems;

Evaluation of the potential of fraud and how the organization manages fraud risk; Evaluation of the adequacy and effectiveness of controls responding to risks within the organization's governance, operations, and information systems;

Developing of work programs in order to achieve the engagement objectives; To base the conclusions and engagement results on appropriate analyses, evaluations and by providing relevant document to support them; 
Accurate, objective, clear, concise, constructive, complete, and timely communications;

The system to monitor the disposition of results/findings, aiming to monitor that management actions have been implemented.

The arithmetic means of the respondent's answers of this field are high reached to (4.41), and the standard deviations were (0.41).

Table 3. Factors influencing the Performance Standards

\section{Descriptive Statistics}

\begin{tabular}{|l|c|c|}
\hline Statements & Mean & Std. Deviation \\
\hline $\begin{array}{l}\text { The chief audit executive must establish risk-based plans to determine the priorities of the internal audit } \\
\text { activity, consistent with the organization's goals. }\end{array}$ & 4.58 & 0.502 \\
\hline $\begin{array}{l}\text { The chief audit executive must communicate the internal audit activity's plan and resource requirements to } \\
\text { senior management and the board for review and approval. }\end{array}$ & 4.12 & 0.927 \\
\hline $\begin{array}{l}\text { The chief audit executive must ensure that internal audit resources are appropriate, sufficient, and effectively } \\
\text { deployed to achieve the approved plan. }\end{array}$ & 4.52 & 0.619 \\
\hline The chief audit executive must establish policies and procedures to guide the internal audit activity. & 4.34 & 0.787 \\
\hline $\begin{array}{l}\text { The chief audit executive should share information and coordinate activities with other internal and external } \\
\text { providers of assurance and consulting services to ensure proper coverage and minimize duplication of efforts. }\end{array}$ & 3.76 & 1.091 \\
\hline $\begin{array}{l}\text { The internal audit activity must evaluate the risk exposures relating to the organization's governance, } \\
\text { operations, and information systems. }\end{array}$ & 4.36 & 0.549 \\
\hline The internal audit activity must evaluate the potential of fraud and how the organization manages fraud risk. & 4.42 & 0.561 \\
\hline $\begin{array}{l}\text { The internal audit must evaluate the adequacy and effectiveness of controls responding to risks within the } \\
\text { organization's governance, operations, and information systems. }\end{array}$ & 4.55 & 0.506 \\
\hline $\begin{array}{l}\text { Work programs/checklists must be developed and documented by Internal auditors in order to achieve the } \\
\text { engagement objectives. }\end{array}$ & 4.64 & 0.489 \\
\hline $\begin{array}{l}\text { Internal auditors must base conclusions and engagement results on appropriate analyses, evaluations and by } \\
\text { providing relevant document to support them. }\end{array}$ & 4.61 & 0.556 \\
\hline Communications must be accurate, objective, clear, concise, constructive, complete, and timely. & 4.67 & 0.479 \\
\hline $\begin{array}{l}\text { The chief audit executive must establishes and maintain a system to monitor the disposition of } \\
\text { results/findings, aiming to monitor that management actions have been implemented. }\end{array}$ & 4.42 & 0.502 \\
\hline TOTAL FIELD & $\mathbf{4 . 4 1 4 1}$ & $\mathbf{0 . 4 1 1 1 5}$ \\
\hline
\end{tabular}

\section{Dependent Variable: Internal Audit Quality}

Five factors were used to reflect the quality of the internal auditor. In table (4) are provided the results of the questionnaire concerning the level of importance given by internal auditors to each factor. As can be seen from the table, the majority of the respondents consider factors such as: Internal Audit must provide reasonable assurance for Compliance with policies, procedures, laws and regulations; Internal Audit must provide reasonable assurance for Accomplishment of business goals and objectives; Internal Audit must provide reasonable assurance for Reliability of financial and operating information; Internal Audit must provide reasonable assurance for Economic and efficient use of resources; Internal Audit must provide reasonable assurance for safeguarding of assets.

The arithmetic means of the respondent's answers of this field are high reached to (4.12), and the standard deviations were (0.76).

Table 4. Factors of internal audit quality

\begin{tabular}{|c|c|c|}
\hline \multicolumn{3}{|l|}{ Descriptive Statistics } \\
\hline Statements & Mean & Std. Deviation \\
\hline $\begin{array}{l}\text { Internal Audit must provide reasonable assurance for Compliance with policies, procedures, laws and } \\
\text { regulations. }\end{array}$ & 4.30 & 0.770 \\
\hline Internal Audit must provide reasonable assurance for Accomplishment of business goals and objectives. & 3.79 & 1.023 \\
\hline Internal Audit must provide reasonable assurance for Reliability of financial and operating information. & 4.30 & 0.770 \\
\hline Internal Audit must provide reasonable assurance for Economic and efficient use of resources. & 4.12 & 0.857 \\
\hline Internal Audit must provide reasonable assurance for Safeguarding of assets. & 4.09 & 1.071 \\
\hline TOTAL FIELD & 4.1212 & 0.76148 \\
\hline
\end{tabular}




\section{Testing Research Hypotheses}

The second objective of the study was to empirically examine whether there is a relationship between the statements mentioned above and the internal audit quality. This section reports the results of testing the research hypotheses using correlation analysis.

Table (5) indicates that the value of correlation coefficient (r), for the independent variables attribute standards and performance standards toward the dependent variable quality of internal audit is respectively $(0.418)$ and $(0.420)$, which means that the independent variables have a moderate positive correlation with the dependent variable quality of internal audit.

The coefficient is positive, indicating that these variables are related in a positive linear sense (when one variable increases, the other increases). The correlation table also gives the probability of being wrong if we assume that the relationship we find in our sample accurately reflects the relationship between dependent variable and independent variables that exist in the total population from which the sample was drawn (labeled as Sig. (2-tailed)). The probability value for independent variables Attribute Standards and Performance Standards is respectively (0.008) and (0.007), being well below the conventional threshold of $p<0.05$.

Thus, our hypotheses are supported. There is a relationship between attribute and performance standards of the internal audit and the quality of the internal audit (the coefficient is medium considering the range of the correlation coefficient from -1 to 1). The coefficient is in the predicted direction (positive), and we can generalize the results to the population $(p<0.05)$.

Table 5. Results of the correlation analysis

\begin{tabular}{|c|c|c|c|}
\hline & Quality & Performance & Attribute \\
\hline Pearson Correlation Quality & 1.000 & 0.420 & 0.418 \\
Performance & 0.420 & 1.000 & 0.819 \\
Attribute & 0.418 & 819 & 1.000 \\
\hline Sig. (2-tailed) Quality & 0 & 0.007 & 0.008 \\
Performance & 0.007 & 0 & 0.000 \\
Attribute & 0.008 & 0 & 0 \\
\hline N Quality & 33 & 33 & 33 \\
Performance & 33 & 33 & 33 \\
Attribute & 33 & 33 & 33 \\
\hline
\end{tabular}

It also investigated if there are any significant differences between some demographic components; gender, and work experience and perceptions of the attribute and performance standards. In order to investigate this, it is preferred to use parametric tests; independent t-test and ANOVA applied owing to measurement level of data and number of groups (Smith, 2011).

According to results of the t-tests (used for gender) and ANOVA (used for work experience) there are not any perception differences on the attribute and performance standards by the gender and work experience of the respondents.

\section{Conclusion}

The first objective of this study was to provide evidences about the perceptions on the attributes and performance standards of internal auditors and their influence on the audit quality in Albanian banking industry. The second objective of the study was to examine the relationship, if any, between the attribute and performance standards of internal auditors and the quality of internal audit in Albanian banking industry.

In order to achieve these objectives, a questionnaire it was prepared and distributed to internal auditors working at the Albanian banking industry. From this investigation it was concluded that the internal auditors working in the Albanian banking industry go along with the principles defined in the International Professional Standards issued by The Institute of Internal Auditors, considering these principles as crucial for the quality of the internal audit. The International Professional Attribute Standards and Performance Standards mean scores were respectively (4.42) and (4.41).

As regard the second objective, the results of the correlation indicated that internal auditor's performance standards influences the internal audit quality by $42 \%$, while the attribute standards affects the internal audit quality by $41.8 \%$.

This study did not aim to explore compliance of standards in Albania. We examined internal auditors' perceptions 
on the standards. Internal auditors have positive views on the standards. On one hand the results of this study explored that the standards are reasonable for implementation and have certain degree of quality to be globally unified accepted standard set. On the other hand, internal auditors and banking industry in Albania have been adopting/adopted successfully necessities of the capitalistic economic order even though country ruled by very tough socialist economic regime before two decades.

As a conclusion, it is recommended to the banks operating in Albania to take into consideration the crucial principles for the practice of internal auditing, in order to achieve the quality of internal audit function within banking organization.

\section{References}

Abdolmohammadi, M. J. (2009). Factors Associated with the Use of and Compliance with the IIA Standards: A Study of Anglo-culture CAEs. International Journal of Auditing , 27-42.

Abdolmohammadi, M. J., \& Sarens, G. (2011). An Investigation of the Association between Cultural and Variations in Perceived Use of and Compliance with Internal Auditing Standards in 19 Countries. The International Journal of Accounting , 46, 365-389.

Al Matarneh, F., G. (2011) "Factors Determining the Internal Audit Quality in Banks-Empirical Evidence from Jordan", International Research Journal of Finance and Economics, ISSN 1450-2887 Issue 73.

Bank for International Settlements, (2012) Principles for enhancing corporate governance. Basel Committee on Banking Supervision, October 2010. BCBS website: http://www.bis.org/publ/bcbs176.pdf). Accessed on August 2012.

Bank of Albania, Annual Report 2011, available at, www. Bankofalbania.org/web/Annual Report 2011 accessed on September 2012.

Brody R. G, and Lowe D. (2003), "The New Role of the Internal Auditor: Implications for Internal Auditor Objectivity", International Journal of Auditing Volume 4, Issue 2, pages 169-176.

Burnaby, P. A., \& Hass, S. (2011). Internal auditing in the Americas. Managerial Auditing Journal , 26 (8), 734-756.

Butcher, K., Harrison, G., \& Ross, P. (2013). Perceptions of Audit Service Quality and Auditor Retention. International Journal of Auditing , 54-74.

Cadbury Committee, Report of the Committee on the Financial Aspects of Corporate Governance (London: Professional Publishing Ltd., 1992).

Daniels, B. W., \& Booker, Q. (2011). The effects of audit firm rotation on perceived auditor independence and audit quality. Research in Accounting Regulation , 78-82.

DeAngelo, L. E. (1981). Auditor size and audit quality. Journal of Accounting and Economics, 3(3), 183-199.

Faudziah, H.F, Hasnah, H, and Muhamad, J (2005). "Internal Auditing Practices and Internal Control System", Managerial Auditing Journal, Vol. 20 Iss. 8, pp.844 - 866.

Gill, G. E., Hernandez, M. S., \& de Lema, D. G. (2012). Internal audit and financial reporting in the Spanish banking industry. Managerial Auditing Journal , 27 (8), 728-753.

Hayes, R., Dassen, R., Schilder, A., \& Wallage, P. (2005). Principles of Auditing An Introduction to International Standardson Auditing. Essex, UK: Pearson Education.

Hermanson, D. R., \& Rittenberg, L. E. (2003).

IIA Standards International Standards for the Professional Practice of Internal Auditing, October 2010 https://na.theiia.org/standardsguidance/Public\%20Documents/IPPF_Standards_2011-011.pdf. Accessed on September 2012

Karcioglu, R., \& Yanik, R. (2010). Uluslararasi ic denetim standartlari ve Turkiye'nin ilk 500 buyuk sanayi kurulusunda bir uygulama . Ataturk Universitesi Iktisadi ve Idari Bilimler Dergisi, 24(4), 229-241.

Law No. 9662, dated 18.12.2006 amended by Law No 10481, dated 17.11.2011 "On banks in the Republic of Albania". Available at: http://www.bankofalbania.org/web/Law_No_9662_dated_18_12_2006_amended_by_Law_No_10481_dated_17_11_20_3181_2. php?kc=0,28,0,0,0. Accessed on August 2012.

Law No 8269 dated 23.12.1997 "On Bank of Albania". http://www.bankofalbania.org/web/Law_No_8269_dated_23_12_1997_On_ Bank_of_Albania_204_2.php?kc=0,28,0,0,0. Accessed on August 2012.

Muceku, H., \& Korsita, B. (2010). The Role of Internal Auditing Activity To Improve Management and Increase The Value Of Public Entities. Journal of Studies in Economics and Society, Alexander Moisiu University , II (1), 181-195

Salehi, M., Arianpoor, A., \& Salehi, F. (2013). Investigating the Effect of Internal Audit on the Performance. Journal of Accounting Business \& Management, $46-58$.

Savčuk, O. (2007). Internal Audit Efficiency Evaluation Principles. Journal of Business Economics and Management, (4), 275.

Sekaran, U, and Bougie, R. (2010). Research Methods for Business: A Skill Building Approach (5th Edition) Wiley.

Shkurti R., Leka B., Bahiti R., Manoku E. (2011). Changes in financial and accounting environment in Albania and the impact on practitioners. Annales Universitatis Apulensis Series Oeconomica, 1(13).

Smith, M. (2011). Research Methods in Accounting. London, Sage Publications Ltd..

Steyn, B., Barac, K., Motubatse, K. N., \& Plant, K. (2013). Views on the applicability of the internal audit standards and competencies for internal auditors: an African perspective. Southern African Journal of Accountability and Auditing Research , 3-16. Vol.15 